Available online at http://jurnal.goretanpena.com/index.php/JSSR

\title{
LITERASI DIGITAL KEKINIAN AGAR KOMUNIKASI LEBIH BERMAKNA
}

\author{
Rizky Fauziah \\ STMIK Royal, Kisaran \\ e-mail: rizkyfauziahlbs@gmail.com
}

\begin{abstract}
As a society that grows in an era of rapid technological development, it will certainly be connected to each other. Currently, the high level of use of social media and the ease of accessing information cannot be doubted. However, there are still people who are still consumed by hoax news. Not to mention the emergence of a new phenomenon, namely Fear of Missing Out (FOMO) which can make social users feel restless if they miss the trending things that are happening on social media. In addition, this also causes a decrease in the quality of communication that occurs due to social media and the FOMO phenomenon. This is what makes the importance of digital literacy given so that people who grow up in this era can be more proficient in using digital media, especially social media, and make communication more meaningful by also applying the Joy of Missing Out (JOMO) phenomenon, which is enough even though only opening the media. social for a while. Digital literacy is needed so that activities related to digital media can bring positive things to its users.
\end{abstract}

Keywords: Digital Literacy, FOMO, Social Media, JOMO

\begin{abstract}
Abstrak: Sebagai masyarakat yang tumbuh di era perkembangan teknologi yang begitu pesat, tentu akan saling terhubung satu sama lain. Saat ini tingginya tingkat penggunaan media sosial serta mudahnya dalam mengakses informasi sudah tidak bisa diragukan lagi. Namun masih saja ada masyarakat yang masih termakan oleh berita Hoax. Belum lagi muncul fenomena baru yaitu Fear of Missing Out (FOMO) yang bisa membuat pengguna media sosial merasa gelisah jika ketinggalan dengan yang sedang terjadi di media sosial. Selain itu hal ini juga meyebabkan turunnya kualitas komunikasi yang terjadi karena media sosial maupun fenomena FOMO. Hal inilah yang membuat pentingya literasi digital diberikan agar masyarakat yang tumbuh di era ini bisa semakin cakap dalam menggunakan media digial terutama media sosial, dan membuat komunikasi lebih bermakna dengan juga menerapkan fenomena Joy of Missing Out (JOMO) yang sudah merasa cukup walau hanya membuka media sosial sebentar. Literasi digital diperlukan agar kegiatan yang menyangkut dengan media digital bisa membawa hal positif untuk penggunannya.
\end{abstract}

Kata kunci: Literasi Digital, FOMO, Media Sosial, JOMO

\section{PENDAHULUAN}

Literasi digital merupakan suatu kemampuan seseorang dalam memahami, menganalisis, dan mengevaluasi suatu informasi dengan menggunakan teknologi digital saat ini. Literasi digital memililiki pengaruh yang akan menciptakan masyarakat dengan pola pikir, membangu komunikasi serta pandangan yang kritis dan kreatif terhadap media digital. Masyarakat tidak akan mudah termakan oleh isu yang provokatif, menjadi korban informasi berita hoax dan penipuan yang berbasis digital. Dalam membangun budaya literasi digital tentu perlu melibatkan peran masyarakat secara bersama-sama. Setiap individu perlu memahami bahwa literasi digital merupakan hal penting yang dibutuhkan 
Available online at http://jurnal.goretanpena.com/index.php/JSSR

untuk dapat ikut serta di dunia modern sekarang. Mengingat bahwa saat ini, sangat mudah mendapatkan informasi, karena media digital memudahkan untuk saling berbagi informasi dan saling berkomunikasi satu sama lain. Untuk itulah perlunya literasi digital agar generasi yang tumbuh dengan akses yang tidak terbatas dalam teknologi digital, mempunyai pola pikir yang lebih luas. Karena dalam menggunakan media digital saat ini perlu kemampuan, pemahaman dan pengetahuan dalam menggunakannya. Siapapun dapat dengan mudah memanfaatkannya dengan baik, namun ketidakpahaman masyarakat dalam menggunakan media digital terlebih dalam menggunakan media sosial, justru akan bisa berakibat terhadap kehidupan pribadi maupun sosial jika disalahgunakan. Tentunya setiap orang harus beranggung jawab dalam menggunakan teknologi.

Teknologi digital saat ini membantu masyarakat untuk berinteraksi dan berkomunikasi jarak jauh, tentunya dengan keluarga dan teman teman lainnya di kehidupan sehati-hari. Namun saat ini dunia digital semakin dipenuhi oleh konten-konten yang berbau penipuan, berita hoax, ujaran kebencian, radikalisme dan banyak lainnya. Tentunya keberadaan konten yang negatif ini akan merusak tatanan digital saat ini, dan hanya bisa ditangkal dengan membangun kesadaran dari masyarakat itu sendiri. Dalam hal ini, literasi digital membantu masyarakat agar dapat memproses berbagai informasi dalam bentuk apapun, agar masyarakat dapat menelaah, memahami kapan dan bagaimana teknologi harus digunakan dengan efektif untuk menciptakan konten-konten yang bermanfaat. Termasuk pula kesadaaran dan berpikir kritis terhadap barbagai dampak positif maupun negatif yang mungkin akan terjadi dalam penggunaan teknologi di kehidupan sehari hari. Jika saat ini generasi muda kurang menguasai literasi digital di era digital saat ini, hal ini akan sangat fatal bagi mereka untuk mencegah konten konten negatif yang ada di teknologi digital dan akan sulit dalam berinteraksi sosial.

Saat ini dalam menggunakan media sosial sangat penting untuk memahami literasi digital. Kehadiran media sosial di era digital ini menawarkan cara berkomunikasi, berinteraksi dan bersosialisasi dengan mudah dengan dukungan fitur-fitur yang menarik. Saat ini jumlah pengguna media sosial di Indonesia lebih banyak dikalangan remaja. Penggunaan yang baik dapat meningkatkan prestasi, sebaliknya penggunaan yang buruk dapat berakibat negatif terhadap diri anak dan remaja (Retnowati, 2015). Banyak jenis media sosial yang digunakan diantaarnya seperti Instagram, Twitter, TikTok, WhatsApp, dan banyak lainnya. Media sosial dipilih karena bisa mendapatkan dan menyebarkan informasi yang lebih cepat. Kecepatan informasi inilah yang menyebabkan pergeseran masyarakat dalam mengakses informasi, yang dulunya masyarakat hanya bisa mendapatkan informasi melalui portal berita.

Persebaran informasi yang begitu cepat melalui media sosia mnyebabkan munculnya berita hoax (informasi yang tidak benar). Berita hoax tercipta karena pengguna media sosial ingin mendapatkan respon dari pngguna sosial media. Contoh sosial media yang banyak digunakan untuk penyebaran berita hoax saat ini adalah WhatsApp. Karena WhatsApp merupakan aplikasi ketiga yang banyak digunakan setelah Youtube dan Facebook serta aplikasi yang digunakan sebelm Line (Alfarizi, 2018).

Banyak masyarakat saat ini di kalangan remaja maupun orang tua menggunakan aplikasi WhatsApp karena dalam penggunaanya yang mudah dan praktis. Di media sosial ini pengguna pengguna dapat mengirim pesan suara maupun teks, mengirim foto, video dan melakukan panggilan suara dan video, 
Available online at http://jurnal.goretanpena.com/index.php/JSSR

dan pengguna WhatsApp bisa
berkomunikasi secara kelompok
menggunakan fitur WhatsApp Grup.
Karena mudahnya dalam penggunaan,
persebaran informasi lewat WhatsApp
sangat cepat di pesan pribadi maupun
WhatsApp Grup, hal inilah yang membuat
banyak berita hoax tersebar. Karena
pengguna Whatsapp rata-rata
penggunaanya di kalangan remaja dan
orang tua yang kurang memahami literasi
digital dan menelaah informasi yang
didapatkan. Sehingga ketika mendapatkan
informasi mereka langsung menyebarkan
informasi tersebut ke WhatsApp Grup
maupun ke pengguna WhatsApp secara
pribadi.

Persebaran di dunia nyata maupun di media sosial itu sama, informasi yang terbaru, aneh, dan berbeda akan menibulkan ketetarikan pada informasi tersebut. Saat seperti orang yang memberikan informasi yang menarik namun ia berbohong tentang satu hal yang baru, tentu akan banyak orang yang berdatangan untuk mendengarkan informasi tersebut tanpa bertanya kebenaran informasi yang didapatkan. Begitu pula perkembangan dan kecepatan informasi di WhatsApp, jika mendapatkan informasi yang menarik langsung di sebar ke pengguna WhatsApp, tanpa mencari tahu kebenaran akan informasi tersebut.

Kemajuan teknolohgi yang semakin pesat membuat penyebaran informasi yang dulunya menggunakan data pulsa dan sekarang bisa mengunakan kouta yang gratis dengan tersambung Wifi. Sebelumnya masyarakat dalam mengirim informasi masih berfikir ulang untuk membagikan pesan dengan kalimat yang panjang, namun sangat berbeda dengan sekarang, masyarakat dengan mudahnya membagikan informasi melalui WhatsApp. Informasi yang didapatkan dan telah dikirm ke pengguna WhatsApp dapat mempengaruhi emosi, perasaan, pikiran bahkan tindakan. Sangat disayangkan jika informasi yang disampaikan adan informasi yang kebenarannya tidak akurat apalagi jika berita tersebut hoax dengan judul yang sangat provokatif, hal itu pula yang akan membuat opini negatif, fitnah dan menjadi ujaran kebaencian sehingga menyerang pihak yang bersangkutan. Hal ini tentu akan sangat merugikan pihak yang tidak bersalah. Untuk itulah perlunya pembekalan kepada masyarakat agar mencari tahu terlebih dahulu apakah informasi yang didapatkan adalah berita hoax atau tidak dengan literasi digital, agar informasi tidak disebarluaskan ketika berita tersebut tidak benar. Selain berita hoax, di media sosial WhatsApp sering juga terjadi penipuan dan pencurian data. Biasanya pengguna WhatsApp mendapatkan pesan yang isinya terdapat link menuju website tertentu. Pencurian data bisa terjadi jika pengguna WhatsApp membuka link tersebut. Hal ini bisa terjadi karena isi pesan yang sangat menarik seperti, mendapatkan kouta gratis, mendpatkan voucher belanja, dan banyak lagi. Pencurian data ini biasa dikenal dengan Phishing yang artinya memancing korban untuk membuka link tersebut agar datanya bisa dicuri. Biasanya data yang dicuri seperti akun email, no hp, no rekening dan informasi pribadi yang sangat penting. Jika hal ini terjadi maka akibatnya akan sangat merugikan. Untuk itulah masyarakat harus memahami literasi dan menelaah lagi dalam menggunakan sosial media, agar dalam penggunaaan sosial media tidak kerap menimbukan masalah

Selain luasnya penyebaran berita hoax yang terjadi saat ini, muncul fenomena baru yaitu FOMO (Fear of Missing Out). FOMO merupakan kecemasan sosial yang merasa takut akan tertinggal terhadap apa yang sedang terjadi. Fenomena ini menyebabkan seseorang melakukan sesuatu yang tidak wajar. Secara umum fenomena FOMO ada karena keinginan yang tidak dapat di kontrol untuk tetap terhubung dengan media sosial. Seseorang yang mengalami FOMO akan merasakan takut ketinggalan berita-berita, 
Available online at http://jurnal.goretanpena.com/index.php/JSSR

trending di media sosial dan merasa cemas jika tidak mengakses media sosial. Jika dilihat sekilas fenomena ini terlihat wajar karena perkembangan teknologi sekarang yang sangat cepat dan banyak masyarakat yang selalu up to date. Namun hal ini jika sangat bebahaya untuk psikologis yang mengalami fenomena FOMO akut. Tentu hal ini akan berdampak buruk karena FOMO akan membuat seseorang cenderung sering membandingkan dirinya dengan orang lain di sosial media. Mungkin seseorang yang tidak up to date di media sosial merasa dikucilkan dari lingkungan sekitranya, sehingga membuatnya memiliki kecenderungan fenomena FOMO agar selalu terhubung dengan orang lain secara online tanpa harus bertatap muka secara langsung.

Media sosial tentu telah menjadi faktor yang sangat berpengaruh terhadap fenomena FOMO. Karena media sosial menyediakan tempat yang mudah diakses dan pusat orang orang yang selalu update mencari tahu apa yang dilakukan oleh orang lain. Sebelum adanya kemajuan media sosial yang pesat ini, biasanya orang orang hanya tahu apa yang dilakukan orang lain ketika bersamasama. Namun sekarang, orang-orang dapat mencari tahu apa saja yang dilakukan oleh orang-orang hanya dengan menggunakan media sosial. Fenomena FOMO memiliki dampak yang buruk dan akan selalu kecanduan smartphone.

Berbeda dengan FOMO ada istilah lain yang berkebalikan yaitu fenomena JOMO. JOMO (Joy of Missing Out) merupakan suatu gaya hidup yang tidak peduli dengan trending yang ada di media sosial dan sudah merasa cukup, sehingga merasa lebih bebas dan fokus terhadapa hal-hal yang disenangi. Menerapkan fenomena JOMO di kehidupan sehari-hari akan lebih cenderung lebih tenang dalam menjalani hidup tanpa merasa takut melewakan kesenangan bersama orang lain di media sosial. Fenomena JOMO diharapkan dapat melatih seseorang dalam mengendalikan emosi dan obsesi yang berlebihan terhadap penggunaan smartphone maupun media sosial. Selain beristirahat dari media sosial dengan menerapkan hidup JOMO, seseorang dapat menyisakan waktunya untuk melakukan kegiatan yang bermanfaat, tenaga, dan emosi. Menerapkan fenomena JOMO bukan berarti harus benar-benar menghilang dan tidak bersosialisasi dengan orang-orang disekitar maupun di media sosial. Namun dengan kadar yang secukupnya dalam menggunakan media sosial.

\section{METODE}

Metode yang digunakan dalam penelitian ini meliputi metode deskriptif.

Pada metode ini data yang ada dikumpulkan, disusun, dikelompokkan dan dianalisis sehingga diperoleh beberapa gambaran yang jelas pada masalah yang akan dibahas. Sementara pengumpulan data dilakukan dengan metode-metode sebagai berikut :

1. Observasi, metode pengumpulan data melalui pendekatan ke lapangan dengan mengambil data-data yang ada di lapangan atau melakukan peninjauan secara langsung ke objek yang diteliti.

2. Wawancara (Interview), sejalan dengan observasi penulis melakukan wawancara

3. Dokumen,penulis mengumpulkan berupa dokumen-dokumen yang diperlukan dari tempat-tempat riset terkait yang digunakan untuk keperluan penelitian.

\section{HASIL DAN PEMBAHASAN}

Keadaan literasi digital saat ini kehidupan masyarakat saat ini sangat berkembang pesat akibat perkembangan teknologi yang sudah semakin maju. Perkembangan teknologi membawa perubahan yang sangat terasa di kehidupan masyarakat. Setelah lahirnya media sosial tentu menjadi salah satu faktor yang menjadikan pola kehidupan 
Available online at http://jurnal.goretanpena.com/index.php/JSSR

masyarakat mengalami pergeseran, baik budaya, etika dan norma yang ada. Literasi digital di Indonesia saat ini masih menjadi tantangan. Seperti yang diketahui, Indonesian memiliki jumlah penduduk yang besar dengan berbagi kultur budaya, suku, ras agama yang beragam, tentunya dari berbagai kalangan memiliki dan menggunakan media sosial. Karena hal itu, saat ini Indonesia berusaha menanamkan literasi digital ke masyarakat agar semakin cakap dalam menggunakan media digital salah satunya media sosial. Dengan literasi digital, masyarakat akan memanfaatkan dengan baik dalam menggunakan media sosial.

Namun saat ini literasi digital di Indonesia belum terbilang baik. Kemampuan dalam mengenali berita hoax pada pengguna media sosial masih rendah. Hal ini terbukti masih banyaknya berita hoax yang tersebar di media sosial WhatsApp. Dampak negatif dari media sosial muncul akaibat kurangnya memahami literasi digital dan bagaimana dalam beraktivitas di dunia digital. Maraknya penggunaan media sosial yang selalu kerap membuat masalah, yang menjadikan tempat media sosial bukan lagi sebagai tempat berinteraksi dan komunikasi dengan pengguna lainnya. Saat ini media sosial bisa dijadikan menyampaikan hujatan yang berdalih pendapat dengan menggugah kata-kata kebencian yang tidak etis terhadap orang lain, sehingga terbangun opini rasa tidak senang dan benci terhadap sesorang, baik public figure maupun mereka yang memiliki posisi di pemerintahan. Media sosial saat ini juga bisa dijadikan sarana untuk mencaci-maki bahkan memprovokasi orang lain. Selain ini media sosial digunakan untuk penyebaran berita hoax untuk mempengaruhi masyarakat terhadap berita bohong.

Maraknya penggunaan media sosial yang kerap menimbulkan masalah, namun disamping itu media sosial masih berguna untuk masyarakat. Masyarakat yang paham akan pentingnya lliterasi digital berusaha menggunakan media sosial secara maksimal agar tidak ada pihak yang dirugikan. Masyarakat juga berusaha agar terhindar dari fenomena FOMO yang saat ini terjadi. Masyarakat menerapkan fenomena JOMO yang membuat mereka menggunakan secukupnya dalam menggunakan media sosial untuk kepentingan mereka. Salah satunya seperti membuat konten yang bermanfaat, menggunakan media sosial sebagai media untuk berbisnis, berdiskusi, bekerja, berkomunikasi dan berinterksi, meyampaikan pendapat yang sehat, intinya adalah memanfaatkan dan menggunakan media sosial dengan sebaik-baiknya walaupun saat ini masih banyak masalah yang ditimbulkan oleh pihak yang tidak bertanggung jawab, namun masih ada masyarakat sekarang yang benar-benar sehat dalam menggunakan sosial media walaupun perkembangan media sosial yang sangat pesat.

1. Penerapan Literasi Digital

Dalam literasi digital, mungkin banyak masyarakat yang kurang paham dalam penggunaan media sosial, agar media sosial mejadi tempat yang nyaman. Berikut beberapa cara dalam menerapkan literasi digital dengan menggunakan sosial agar tidak menimbulkan masalah:

\section{Tidak Asal Dalam Memposting Konten}

Dalam memposting sebuah konten, sadari bahwa media sosial bisa dilihat secara publik, termasuk isi postingan didalamnya. Oleh sebab itu, bijaklah dalam membuat/memilih konten-konten yang akan di unggah ke media sosial. Telusuri konten tersebut, apakah informasi didalamnya adalah benar dan tidak mengandung berita hoax. Meski beberapa sosial media saat ini mempunyai fitur privasi yang dapat diatur, namun tetap saja tidak ada salahnya jika dalam menggunakan media sosial dengan baik agar bermanfaat sehingga tidak ada pihak 
Available online at http://jurnal.goretanpena.com/index.php/JSSR

yang tersinggung dan dirugikan karena konten yang diposting di media sosial.

\section{Tidak Mencantumkan Informasi Pribadi \\ Semakin canggih perkembangan} teknologi saat ini semakin canggih pula kejahatan cyber. Menggunakan akun media sosial, disarankan jangan mencantumkan informasi pribadi, karena itu akan memudahkan orang yang berbuat jahat akan menemukan kita dan kita tidak akan pernah tahu ancaman-acaman apa yang akan mengintai. Selalu lindungi privasi pribadi.

\section{Menjaga Etika}

Media sosial memberikan kebebasan bereskpresi dan menyampaikan pendapat, namun bukan berarti memberi kebebasan dalam beretika. Dalam menggunakan media sosial, harus menjaga etika, sopan santun dan bersimpati terhadap seseorang yang juga menggunakan media sosial. Hindari menggunkan kata kata yang kasar, tidak pantas maupun kata kata yang mengandung SARA. Hal ini adalah salah satu sikap yang harus dihindari jika masih ingin dihormati dan dihargai ketika menggunakan media sosial.

\section{Berhati-hati dan Selalu Waspada}

Cepatnya dalam penyebaran dan mendapatkan informasi, membuat pengguna media sosial sulit mencari kebenaran akan informasi tersebut. Akan selalu ada saja informasi yang didapatkan dari orang-orang yang tidak bertanggung jawab di media sosial. Misalnya informasi berita hoax, penipuan, dan lain lain yang sering terjadi. Untuk itu perlu selalu berhati-hati dan selalu waspada terhadap informasi yang tersebar dan informasi yang didapatkan dari pengguuna media sosial. Selalu berhati-hati, jika mendapatkan pesan dari penggunapengguna media sosial secara mendadak tanpa ada maksud dan tujuan yang jelas, agar mencegah terjadinya penipuan maupun hal yang tidak diinginkan lainnya.

\section{Memilih Akun Media Sosial Yang} Diikuti

Seriring dengan perkembangan media sosial yang sangat cepat, ternyata kesehatan mental juga diperlukan dalam menggunakannya. Sering kali di media sosial ditemukan dengan postingan tentang kehidupan seseorang yang bisa membuat tidak percaya diri atau bahasa sekarang menyebutnya dengan insecure serta membandingkan dengan kehidupan kita sendiri. Padahal, semua yang ada di media sosial hanya sebagian kecil dari kehidupan yang tidak diketahui kehidupan yang sebenarnya dialami. Orang-orang selalu ingin terlihat perfect di media sosial. Karena hal itulah pentingnya dalam memilih dan mengikuti akun-akun media sosial yang bermanfaat, menghibur, realistis, dan yang sesuai untuk menambah wawasan. Jika peduli dengan kesehatan mental juga hindarilah akun-akun toxic dan tidak memiliki manfaat apapun. Selalu bijaklah dalam bersosial media.

7 Menghargai Karya Orang Lain

Dalam menggunakan media sosial, pengguna mungkin menyebarkan informasi baik itu foto, tulisasn, video maupun lainnya milik orang lain, ada baiknya mencantumkan pemiliknya atau sumber informasi sebagi bentuk penghargaan akan karya yang dimiliki oleh orang tersebut. Agar kita tidak dianggap menjiplak atau copy paste karya milik orang lain. Terlihat mudah, namun hal ini tentu sangat penting, agar pemilik karya tersebut tidak merasa bahwa karyanya dicuri atau disebarluaskan oleh pihak yang tidak bertanggung jawab.

Jika menerapkan literasi digital untuk hal seperti yang diatas, akan sangat terasa sekali perbedaanya dalam menggunakan sosial media. Literasi digital juga sangat membantu dalam menumbuhkan kecakapan dalam komunikasi antar personal dengan media sosial. menerapkan literasi digital akan membantu meningkatkan kualitas komunikasi yang profesianal terhadap 
Available online at http://jurnal.goretanpena.com/index.php/JSSR

pengguna sosial media lainnya. Walaupun tidak begitu mengenal dengan pengguna media sosial lainnya, jika sudah menerapkan literasi digital komunikasi yang terjalin seperti sudah menjadi teman yang akrab.

Disamping itu pula perkembangan teknologi yang semakin pesat namun, jika tidak disertai dengan pemahaman dalam penerapan literasi digital yang baik, saat ini muncul pula fenomena FOMO yang bisa membuat pengguna media sosial kecanduan dengan media sosial. FOMO sangat mempengaruhi komunikasi antar pesonal dalam menggunakan media sosial. sebelum munculnya fenomena FOMO, pengguna media sosial masih dalam batas yang wajar dalam menggunakan media sosial, komunikasi dengan penggunanya sangat bervariatif. Namun setelah munculnya fenomena FOMO, banyak pengguna media sosial yang tidak bisa lepas dari media sosial dan bisa menjadi seseorang yang anti sosial, hal ini akan sangat berpengaruh terhadap kesehatan mental serta kualitas dalam berkomunikasi dengan lingkungan sekitar baik di dunia maya maupun di dunia nyata.

Berikut beberapa pengaruh FOMO dalam kehidupan sehari hari yang menyebabkan komunikasi antar personal kurang berjalan dengan baik:

1.Mengalami Stres

Seringnya dalam mengakses media sosial untuk melihat berbagai trending yang terbaru karena ketakutan akan ketinggalan berbagai informasi yang viral maupun yang sedang populer dibicarakan di media sosial lama kelamaan akan membuat stres. FOMO akan memaksa pengguna untuk selalu melihat smartphone untuk memeriksa notifikasi ataupun menanggappi dengan berkomenar di setiap timeline yang lewat di media sosial. Hal ini akan memicu kelelahan maupun turunnya kesehatan mental karena di picu oleh FOMO

\section{Insecure Dan Merasa Kurang}

Pengaruh FOMO menimbukan perasaan dalam diri atau kehidupan selama ini selalu kurang dan insecure jika dibandingkan denga kehidupan orang lain di media sosial. meski sadar bahwa postingan yang ada di media sosial bisa saja dimanipulasi namun pasti ada saja perasaan iri dan tidak aman dalam diri. Hal ini juga bisa memicu memberikan komentar yang kasar pada akun media sosial yang bersangkutan karena merasa tidak terima dengan kehidupannya lebih baik dibanding dirinya. Akibatnya akan sangat fatal jika hal in tersu menerus dilakukan.

\section{Memicu Kecemasan}

Fenomena FOMO akan memunculkan kecemasan yang ditandai perasaan gelisah dan khawatir yang akan membuat sulit berkonsentrasi. Hal ini karena pengguna media sosial merasa bahwa ia merasa di kucilkan akibat tidak mngeahui apa yang sedang populer maupun viral di media sosial.

\section{Sulit bersosialisasi}

Sebelum adanya fenomena FOMO pengguna medai sosial bersosialisasi dengan pengguna media lainnya maupun dengan lingkungan disekitar. Berkomunikasi satu sama lain membicarakan sesuatu dengan santai. Setelah muncul fenomena FOMO karena sring ketergantung dengan smartphone, sehingga pengguna media sosial sulit bersosialisasi deng lingkungan sekitar karena sibuk bermain media sosial. hal ini sangat berpengaruh terhadap kepribadian seseorang karena bisa saja selalu aktif bermain media sosial namun nyatanya orang yang aktif main media sosial adalah orag yang pendiam dan sulit bergaul di kehidupan yang nyata.

\section{Kecanduan}

Kecanduan merupakan yang paing buruk akibat fenomena FOMO. Penggunaan dalam menggunakan media sosial yang berlebihan akan membuat pengguna sulit untuk lepas dari media sosial agar untuk terus aktif menggunakannya. Jika sudah mengalami 
Available online at http://jurnal.goretanpena.com/index.php/JSSR

kecanduan akan sangat sulit untuk mengurangi dalam menggunakan media sosial. hal ini karena sudah menjadi kesehatan mental yang harus ditangani.

Kurangnya akan kepahaman dalam menerapkan literasi digital dalam menggunakan media sosial membuat fenomena FOMO muncul. Maka dari itulah perlunya bimbingan dalam menerapkan literasi digital. Literasi digital bisa diterapkan kepada anak-anak yang akan mengenal dunia digital. Bukan hanya anak anak saja anak remaja maupun usia lanjutan yang mengunakan teknologi harus dibekali dengan literasi digital. Literasi digital harus diberikan agar mengurangi dampak negatif dari teknologi. Karena hal inilah orang tua maupun keluarga harus mengajarkan dan memberikan pemahaman literasi digital dalam menggunaka media sosial. Karena smartphone juga merupakan alat komunikasi yang paling mudah untuk diakses justru menjadi hal yang sang sulit dilepas oleh anak-anak maupun remaja saat ini. Tentu peran literasi digital sangat penting dalam lingkungan keluarag, berikut beberapa peran literasi digital dalam lingkungkan keluarga yaitu:

1. Meningkatkan Pengetahuan Orang Tua.

Di kondisi saat ini orang tua dianjurkan mengarahkan anggota keluarga ainnya untuk menggunaka akses internet secara sehat dan membatasi media sosial yang digunakan. Kondisi ini tentunya harus dipahami karena saat ini tidak bisa menghindar dari tuntutan zaman untuk selalu menambang pengetahuan mereka tentang teknologi digital dan media sosial. Jika hal ini tidak dilakukan, orang tua akan kesulitan dalam melindungi keluarga dari dampak negatif dari penggunaan media digital. Untuk itulah orang tua harus memahami teknologi digital secara terus menerus.

2. Membuat Komitmen Yang Sehat Dalam Menggunakan Media Sosial Yang Sehat.

Membuat komitmen dengan anggota keluarga dalam menggunakan media sosial haruslah diterapkan. Para orang tua harus bisa membuat peraturan yang harus dipatuhi bersama dalam menggunakan media digital. Misalnya seperti membatasi atau memberikan waktu dalam menggunakan mendia sosial agar tidak terus menerus menggunakan smartphone.

3.Membuat Aktivitas Yang Beragam

Ketergantungan seseorang terhadap media sosial sering kali dimulai karena penggunaan smartphone yang tidak terkontrol. Banyaknya isu yang menarik membuat sulit untuk lepas dari media sosial.Orang tua hari membuat aktivitas yang beragam dengan membuat permainan ataupun aktivitas yang menarik agar tidak kecanduan dalam menggunakan media sosial dan smartphone.

\section{SIMPULAN}

Berdasarkan pembahasan diatas, dapat diambil beberapa kesimpulan sebagai berikut:

1. Seiring dengan berkembang pesatnya perkembangan dunia digital, diperlukan pemahaman literasi digital agar semakin cakap dalam menggunakan media digital terutama media sosial yang sering digunakan.

2. Literasi digital juga membantu agar terbentuknya komunikasi yang kekinian namun terarah dan positif. Di era saat ini seluruh informasi dengan mudah didapatkan melalui media sosial. Semua berita disajikan dengan cepat, namun terkadang tidak akurat dan bisa mengarah ke berita hoax, karena yang paling utama adalah kecepatan dalam memberikan informasi. Berbagi situs ditemukan, akun akun komunitas tertentu bermunculan hingga berbegi informasi baik pribadi maupun tentang orang lain. Hal inilah yang menyebabkan rasa ingin pengguna media sosial meningkat.

3. Memberikan pemahaman tentang literasi digital agar tidak memunculkan fenomena FOMO yang saat ini sudah terjadi. Kecanduan dalam menggunakan 
Available online at http://jurnal.goretanpena.com/index.php/JSSR

media sosial serta sering termakan berita hoax sudah jadi makanan sehari-hari untuk pengguna media sosial yang mengalami fenomena FOMO. Ketika seseorang mengalami fenomena FOMO tentu kualitas dalam berkomunikasi akan berkurang dan kurang bermakna akibat kurangnya pemahaman tentang literasi digital yang juga membantu dalam meningkatkan kualitas komunikasi yang menyesuaikan dengan perkembangan teknologi saat ini atau kekinian.

\section{DAFTAR PUSTAKA}

Akbar, Setiawan Rizki dkk. (2018). Ketakutan Akan Kehilangan Momen (FOMO) Pada Remaja Kota Samarinda. Psikostudia: Jurnal Psikologi. Vol.07, No.2

Amar \& Nurhidayah. (2020). Media Sosial dan Tantangan Masa Depan Generasi Milenial. Jurnal Ilmu Komunikasi. Vol.08, No.2

Ceccep \& Hana Silvana. (2018). Pendidikan Literasi Digital Di Kalangan Usia Muda Di Kota Bandung. Jurnal Ilmu Pendidikan.

Fatmawati, Nur Eka. (2019). Literasi Digital Mendidik Anak Di Era Digital Bagi Orang Tua Milenial. MADANI: Jurnal Politik dan Sosial Kemasyarakatan. Vol.11, No.2

Harjono, Hary Soedarto. (2018). Literasi Digital: Prospek dan Implikasinya dalam Pembelajaran Bahasa. Jurnal Pendidikan Bahasa dan Satra. Vol.08, No.1

Juditha,Christiany. (2018). Interaksi Komunikasi Hoax di Media Sosial Serta Antisipasinya. Jurnal Pekommas. Vol.03, No.1

Lira \& Kiyanti. (2020). Sindrom Fear of Missing Out Sebagai Gaya Hidup Generasi Milenial Di Kota Depok. Jurnal Riset Mahasiswa Dakwah dan Komunikasi (JRMDK). Vol.02, No. 4

Monica \& Gayes. (2019). Prilaku Komunikasi Remaja dengan Kecenderungan FOMO. Jurnal Riset Komunikasi.

Nani \& Nola. (2016). Pengaru Literasi Digital Trehadap Psikologis Anak Remaja. Jurnal Ilmiah Program Studi Pendidilkan Bahasa dan Sastra Indonesia

Rahadi, Dedi Rianto. (2017). Prilaku Pengguna dan Informasi Hoax di Media Sosial. Jurnal Manajemen \& Kewirausahaan (JMDK).Vol..05, No.1

Restianty, Anjani. (2018). Literasi Digital Sebuah Tantangan Baru Dalam Literasi Media. Jurnal Kehumasan. Vol.01, No.1

Risdayanti, Kedya Sara dkk. (2019). Peranan Fear of Missing Out Terhadap Problematis Social Media Use. Jurnal Muara ilmu Sosial, Humaniora, dan Seni. Vol.03, No.1

Seprianus \&Andik. (2019). Dari FOMO ke JOMO: Mengatasi Rasa Takut Akan Kehilangan (FOMO) dan Mnumbukan Resiliensi Terhadap Kergantungan Dari Dunia Digittal. Jurnal PSISULA: Prosiding Berkala Psikologi. Vol.01

Siddik, Satria dkk. (2020). Peran Harga Diri Terhadap Fear Of Missing Out Pada Remaja Pengguna Situs Jejering Sosial. Jurnal Psikologi Teori dan Terapan. Vol.10, No.2

Stella, Stefany dkk. (2017). Literasi Digital dan Pembukaan Diri: Studi Korelasi Penggunaan Media Sosial Pada Pelajar Remaja di Kota Medan. Jurnal Pemikiran dan Penelitian Sosiologi

Sumartono \& Hani. (2019). Etika Komunikasi WhatsApp dan Jarak Sosial Pada Generasi Milenial. Komunikologi: Jurnal Ilmiah Ilmu Komunikasi 